\title{
The Effect of Four Abiotic Factors on Macro-Anatomical Markers Development in Parkia biglobosa, Jack, R. Br., 1830 (Fabaceae) Crown
}

\author{
Beda Innocent Adji ${ }^{1,2,3 *}$, Doffou Sélastique Akaffou ${ }^{1}$, Kouadio Henri Kouassi ${ }^{1}$, \\ Yao Patrice Houphouet ${ }^{1}$, Jerôme Duminil ${ }^{4,5}$, Sylvie Sabatier ${ }^{2,3}$ \\ ${ }^{1}$ Université Jean Lorougnon Guédé, Agroforestry UFR, Daloa, Côte d'Ivoire \\ ${ }^{2}$ CIRAD, UMR AMAP, Montpellier, France \\ ${ }^{3}$ AMAP, Université Montpellier, CIRAD, CNRS, INRAE, IRD, Montpellier, France \\ ${ }^{4} \mathrm{IRD}$, UMR-DIADE, Montpellier Cedex 5, France \\ ${ }^{5}$ DIADE, Université Montpellier, CIRAD, IRD, Montpellier, France \\ Email: ^adjibedainnocent@gmail.com, *beda-innocent.adji@cirad.fr
}

How to cite this paper: Adji, B.I., Akaffou, D.S., Kouassi, K.H., Houphouet, Y.P., Duminil, J. and Sabatier, S. (2021) The Effect of Four Abiotic Factors on Macro-Anatomical Markers Development in Parkia biglobosa, Jack, R. Br., 1830 (Fabaceae) Crown. American Journal of Plant Sciences, 12, 645661.

https://doi.org/10.4236/ajps.2021.124044

Received: March 6, 2021

Accepted: April 26, 2021

Published: April 29, 2021

Copyright $\odot 2021$ by author(s) and Scientific Research Publishing Inc. This work is licensed under the Creative Commons Attribution International License (CC BY 4.0).

http://creativecommons.org/licenses/by/4.0/

\begin{abstract}
Interpretation of primary growth markers (modules) is neglected in sustainable resource management processes, yet it opens up prospects for long time series on tree crown development, necessary for their characterization in the current context of climate change. This study aimed to assess the morphological variation of crown shoots in Parkia biglobosa in the face of a changing environment. Axis growth modules of 420 individuals of different ages were retrospectively analyzed in the presence or absence of shading during the wet and dry seasons in seven localities in Côte d'Ivoire. The results showed that the developmental environment of individuals did not influence the growth modules dimensions $(\mathrm{P}>0.05)$. However, module size remained significantly different between locations $(\mathrm{P}<0.05)$. The southern part of the gradient is still favourable and has priority for the establishment of permanent plots. The modules morphology differs from the youngest to the oldest individuals $(\mathrm{P}<$ 0.05). The rainy season remains the ideal period for the implementation of agroforestry reforestation programmes based on this species $(\mathrm{P}<0.05)$. Parkia biglobosa is a monochasial sympod (Pseudo-monopod) with a relay axis that follows the Paul Champagnat architectural model in the young stage, and transits to the Wilhelm Troll model later in the adult and old stage. This information contributes to the understanding of the functioning of crown and the adaptation of this species to a varying environment. It could guide choice of suitable environment and ideal genotype for the implementation of a reforestation or agroforestry programme based on Parkia biglobosa.
\end{abstract}




\section{Keywords}

Parkia biglobosa, Environment, Development, Growth Modules, Crown

\section{Introduction}

Architectural and retrospective analysis is very important for the monitoring and sustainable management of trees [1] [2]. Architectural analysis allows us to interpret the overall structure of the tree and to understand the morphological mechanisms that gave birth to it; retrospective analysis allows us to trace the past growth of trees via morphological markers left by growth stoppages due to the dry seasons. In fact, the latter provides access to long-term growth series for understanding and interpreting the structural functioning of tree crowns, the choice of resilient and adapted ideotypes, and the choice of environment conducive to the establishment of permanent plots necessary for their sustainable management [3] [4].

Several studies of sustainable management of plant genetic resources via architectural and retrospective analysis have proven effective in Europe and Latin America [5] [6] [7] [8]. These methods have not yet been applied to species in Africa; indeed, studies on architectural and retrospective analysis for the sustainable management of many overexploited species in Africa are almost absent. We believe that these methods should be applied in Africa, specifically in West Africa. This would allow a better understanding of the coordination over time of growth processes (elongation, thickening) of shoots within the crown and the associated morpho-anatomy essential for long-term retrospective analysis of sustainable management, tree development and any analysis of the causes of observed variations [1]. In view of the need to characterise plant responses to current climate change, such retrospective analysis will be welcome as a complement to data from permanent plots.

Our study focused on a well-known tree from sub-Saharan Africa, Parkia biglobosa (Fabaceae), for several reasons: 1 ) it is an emerging tree still in the wild and widely distributed in this area [9];2) it is a beloved and overexploited species for its food, medicinal and socio-cultural function [10] [11];3) it is an agroforestry species with soil restorative properties (Leguminosae) [12]; 4) the genus Parkia has anatomical features suitable for counting annual rings [13]; 5) this specie present unusual morphological features (modules) suitable for determining growth modules or units, which makes it particularly interesting for a retrospective study of savanna tree shoot growth.

This study aimed to characterise the development of growth modules in the crown of Parkia biglobosa in the face of a changing environment in Côte d'Ivoire through retrospective analysis. This approach would allow us to understand: 1) the variability of shoot size in relation to different habitats; 2) the adaptability of the species to various environments; 3 ) to identify genotypes adapted and resis- 
tant to climatic variations and 4) to guide the choice of priority and favourable environments for the establishment of permanent plots (species domestication) within the framework of possible "Néré" based agroforestry programmes in Côte d'Ivoire.

\section{Material and Methods}

\subsection{Plant Material}

The plant material is made up of axis of 420 individuals of different ages chosen randomly and arbitrarily in natural stands according to two types of habitats. The criteria for sorting the age categories, the dendrometric characteristics and the number of individuals per age category and per habitat type as well as the age types examined are recorded in Table 1.

\subsection{Methods}

\subsubsection{Study Sites}

Study was carried out at seven locations in Côte d'Ivoire. The study sites are arranged along a South-North bioclimatic gradient. The localities were chosen according to the specific vegetation to the Parkia biglobosa species (Figure 1). The characteristics of the surveyed locations are recorded in Table 2.

\subsubsection{Observation Method}

\section{1) Individuals selection and sorting by age category}

A total of 420 individuals from natural regeneration were sampled and sorted by age category (young, adult and old). The age of the individuals was arbitrarily chosen on the basis of the size (height and diameter) of individuals raised in nurseries and of individuals present on old plots set up by the CNRA (Centre National de Recherche Agronomique) of Côte d'Ivoire in the 1980s in the Korhogo

Table 1. Age selection criteria, dendrometric characteristics and number of individuals used in relation to age and habitat in Parkia biglobosa.

\begin{tabular}{|c|c|c|c|c|c|c|c|c|c|}
\hline \multirow{2}{*}{ Ages } & \multirow{2}{*}{ Habitats/environments } & \multicolumn{3}{|c|}{$\mathrm{H}(\mathrm{m})$} & \multicolumn{3}{|c|}{$\mathrm{D}$ or $\mathrm{DBH}(\mathrm{cm})$} & \multirow{2}{*}{ - Indiv-Nbr } & \multirow{2}{*}{ Axis examined } \\
\hline & & Mini & Maxi & Mea & Mini & Maxi & Mea & & \\
\hline $\begin{array}{l}\text { Young tree } \\
(1-5 \mathrm{Yr})\end{array}$ & Full sunlight & 0.53 & 5.5 & $1.95 \pm 0.11$ & 0.56 & 18.96 & $4.35 \pm 0.24$ & 70 & Main stem \\
\hline $\begin{array}{l}\mathrm{H}(\mathrm{m}): 0.1-6 \\
\mathrm{D}(\mathrm{cm}): 1-19\end{array}$ & Undergrowth/shading & 0.42 & 5.8 & $2.56 \pm 0.05$ & 1.26 & 17.83 & $7.06 \pm 1.22$ & 70 & Main stem \\
\hline $\begin{array}{l}\text { Adult tree } \\
(6-20 \mathrm{Yr})\end{array}$ & Full sunlight & 7.5 & 11 & $9.68 \pm 1.14$ & 20.06 & 49.68 & $38.19 \pm 3.02$ & 70 & Branch \\
\hline $\begin{array}{c}\mathrm{H}(\mathrm{m}): 7-14 \\
\mathrm{D}(\mathrm{cm}): 20-50\end{array}$ & Undergrowth/shading & 8 & 13.7 & $12.02 \pm 1.01$ & 22.4 & 48.8 & $36.27 \pm 1.53$ & 70 & Branch \\
\hline $\begin{array}{l}\text { Old tree } \\
(21 \mathrm{Yr} \leq)\end{array}$ & Full sunlight & 18 & 31.7 & $25.22 \pm 3.21$ & 61.3 & 178.44 & $85.51 \pm 6.12$ & 70 & Branch \\
\hline
\end{tabular}

Yr $=$ Year old, $\mathbf{H}=$ Height, $\mathbf{D}$ or $\mathbf{D B H}=$ Diameter or diameter at breast height, $\mathbf{M i n i}=$ minimum, Maxi $=$ Maximum, $\mathbf{M o y}=\mathbf{M e a n}, \mathbf{m}=\mathbf{m e t e r}, \mathbf{c m}=$ centimeter, Indiv-Nbr $=$ number of individuals assessed. 
Table 2. Characteristics of the surveyed localities [14]-[28].

\begin{tabular}{|c|c|c|c|c|c|c|}
\hline Sites/locations & GPS coordinates & Vegetation & Climate & $\begin{array}{l}\text { Temperature } \\
\left({ }^{\circ} \mathrm{C}\right)\end{array}$ & $\begin{array}{l}\text { Rainfall } \\
\text { (mm/year) }\end{array}$ & Soil type \\
\hline Ferké & $\begin{array}{c}5^{\circ} 23^{\prime} 43.39644^{\prime \prime} \mathrm{W} \\
9^{\circ} 36^{\prime} 1.87056^{\prime \prime} \mathrm{N}\end{array}$ & $\begin{array}{c}\text { Grassy and little } \\
\text { wooded savannah }\end{array}$ & Dry tropical & $27-40$ & $263-1200$ & $\begin{array}{l}\text { Ferralitics soil (Ferrisols, Cambisols, } \\
\text { Fluvisols, Luvisols), highly to moderately } \\
\text { desaturated. }\end{array}$ \\
\hline Korhogo & $\begin{array}{c}5^{\circ} 36^{\prime} 12.39612^{\prime \prime} \mathrm{W} \\
9^{\circ} 33^{\prime} 24.68988^{\prime \prime} \mathrm{N}\end{array}$ & $\begin{array}{l}\text { Open forest (wooded } \\
\text { savannah) }\end{array}$ & Dry tropical & $26.6-35.7$ & $817-1216$ & $\begin{array}{l}\text { Ferruginous }(90 \%) \text { and Ferralitic ( } 10 \%) \text { : } \\
\text { superficial gravelly soil, deep gravel with a } \\
\text { heavy texture, low in organic matter, } \\
\text { highly desaturated. }\end{array}$ \\
\hline Niakara & $\begin{array}{c}5^{\circ} 18^{\prime} 40.73544^{\prime \prime} \mathrm{W} \\
8^{\circ} 40^{\prime} 47.97912 " \mathrm{~N}\end{array}$ & $\begin{array}{l}\text { Wooded and grassy } \\
\text { savannah }\end{array}$ & Dry tropical & $24.7-38$ & $800-1230$ & $\begin{array}{l}\text { Complex of slightly desaturated ferrallitic } \\
\text { soils and eutrophic brown tropical soils } \\
\text { derived from basic rocks. }\end{array}$ \\
\hline Katiola & $\begin{array}{l}5^{\circ} 7^{\prime} 35.814 " \mathrm{~W} \\
8^{\circ} 13^{\prime} 53.94^{\prime \prime} \mathrm{N}\end{array}$ & $\begin{array}{l}\text { Wooded and grassy } \\
\text { savannah }\end{array}$ & Dry tropical & $24-36$ & $1100-1200$ & $\begin{array}{l}\text { Moderately and highly desaturated } \\
\text { ferrallitic soils }\end{array}$ \\
\hline Bouaké & $\begin{array}{l}5^{\circ} 5^{\prime} 47.3289 " \mathrm{~W} \\
7^{\circ} 40^{\prime} 45.335^{\prime \prime} \mathrm{N}\end{array}$ & $\begin{array}{l}\text { Clear forest (wooded } \\
\text { savannah) }\end{array}$ & Wet tropical & $23.6-34$ & $1100-1200$ & $\begin{array}{l}\text { Gravelly, moderately saturated, reworked, } \\
\text { shallow ferralitic gravel from a granitic } \\
\text { alteration material with a sandy-clay texture. }\end{array}$ \\
\hline Toumodi & $\begin{array}{l}5^{\circ} 1 ' 34.95576 " \mathrm{~W} \\
6^{\circ} 22^{\prime} 42.67848 " \mathrm{~N}\end{array}$ & $\begin{array}{l}\text { Open forest (wooded } \\
\text { savannah. grassland } \\
\text { and gallery forests) }\end{array}$ & Wet tropical & $26.6-30$ & $1092-1200$ & $\begin{array}{l}\text { Ferralitic soil on granitic bedrock } \\
\text { (sandy-clayey soil), characterised by the } \\
\text { weak differentiation and friable } \\
\text { consistency of their horizons. }\end{array}$ \\
\hline Daloa & $\begin{array}{l}6^{\circ} 26^{\prime} 9.19788^{\prime \prime} \mathrm{W} \\
6^{\circ} 54^{\prime} 32.058^{\prime \prime} \mathrm{N}\end{array}$ & Tropical rainforest & Wet tropical & $21-34$ & $1000-1900$ & $\begin{array}{l}\text { Ferralitic, deep, acidic and desaturated in } \\
\text { exchangeable bases, rich in organic matter. }\end{array}$ \\
\hline
\end{tabular}

${ }^{\circ} \mathrm{C}=$ Celsius degree, $\mathrm{mm}=$ millimeter, $\mathrm{W}=$ west, $\mathrm{N}=$ North .

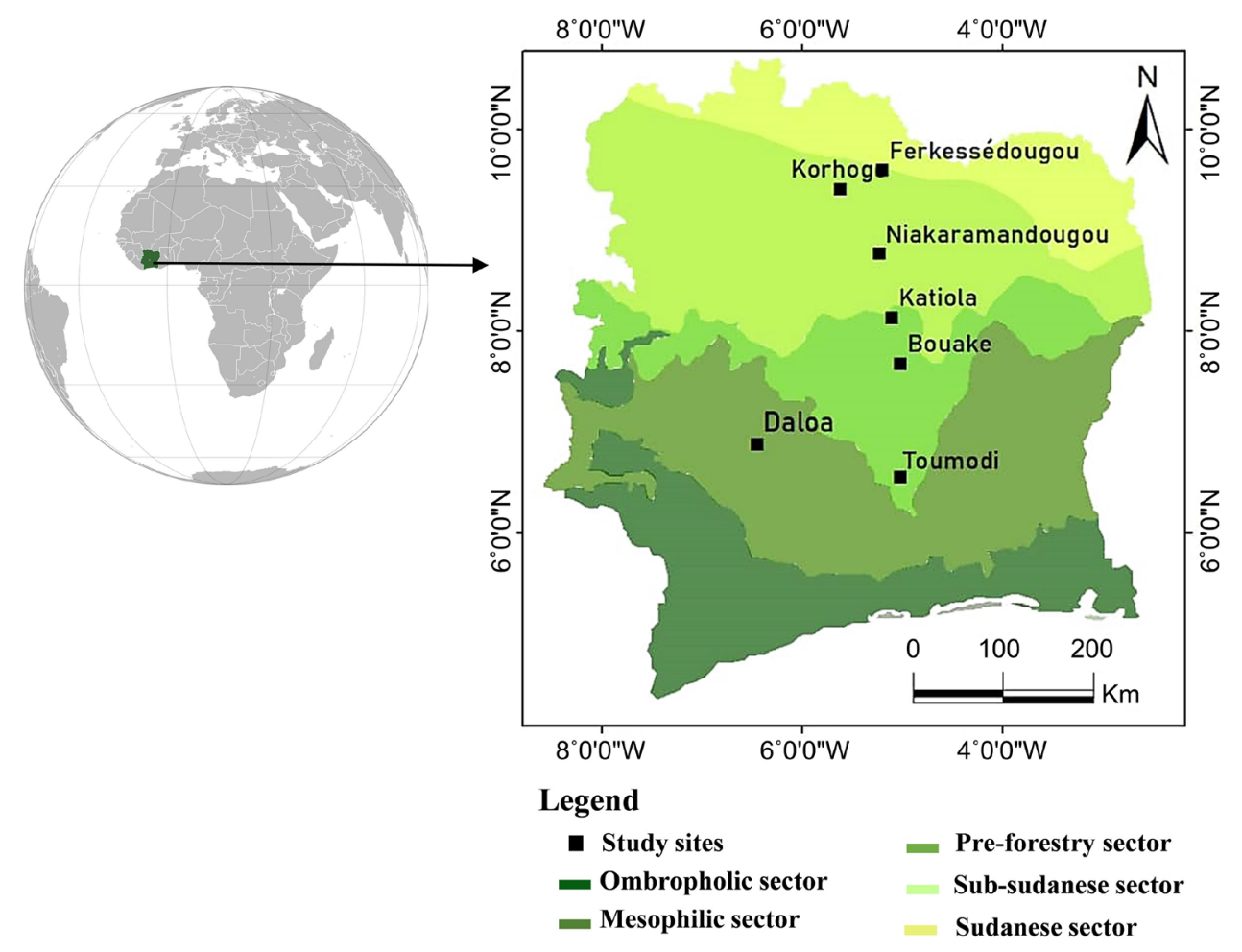

Figure 1. Location of the study area. 
locality. The characteristics of the age groups as well as the criteria for sorting individuals by age category are recorded in Table 1. 10 individuals were identified by chance and evaluated by habitat and age in each locality surveyed in the rainy season (optimal condition) and in the dry season (restrictive condition). We therefore have for each age category (Young, Adult and Old), 10 individuals identified and evaluated by habitat type (Undergrowth/Darkness and Full Sun/ Sun $)$ in each of the 7 localities above $(10 \times 3 \times 2 \times 7=420$ individuals $)$ (Table 1$)$.

\section{2) Choice of axis and habitat type}

Observations were made on different types of axes depending on the accessibility of the crowns in two different habitats. For young trees, the axes assessed were the main trunks because of the easy access and the non-frequency of secondary branches on all individuals in this category. For mature and old trees, the axes assessed were only tertiary branches and short twigs due to accessibility. Assessments were carried out in situ for young trees; whereas for mature and old trees, branches were cut and transported to the laboratory for observations. Two types of environments were considered: undergrowth and full sun. The former refers to individuals living in a very shaded environment with a forest canopy or in an overcrowded environment or with superior shelter. The latter refers to individuals isolated in full sun or in an open environment in direct contact with sunlight.

\section{3) Identification of primary markers (Modules) of growth by analysis}

This analysis is made possible by the recognition of morphological markers that result from the functioning of meristems and that remain for several years. These morphological markers are the scars left by bud scales, cataphylls and deciduous leaves, naturally pruned twigs, a bend in the axis at the site of apical necrosis or trauma, the texture of the bark, etc. The growth unit or elongation unit or morphological unit or extension unit (GU) [6] [8] [29] [30], corresponding to the set of organs (phytomeres) initiated by the apical meristem during an uninterrupted phase of organogenesis and elongation is delimited at its base by a large number of scars of pairs of scales (7 to 16) left by the terminal bud. From this characteristic, it is possible to identify the successive growth units arranged along a leafy stem.

In general, two types of shoots are generated by the establishment of growth units by the terminal bud: monocyclic shoots (establishment of a single growth unit during a year or spring growth wave) and polycyclic shoots (establishment of several growth units during a year or spring and summer growth waves) [3] [6] [32]. If the first GU (spring growth wave) can be qualified as preformed (in the sense of [33]: presence of all the leaf organs of the future GU in the bud before its budburst), some organs in the GU are qualified as neoformed (prolongation of the setting of the leaf organs by the apical meristem in the same time after the preformed organs). In the tropics, the majority of shoots are polycyclic due to a rhythmicity adopted by the growth of species in this zone [33] [34]. This is the case for Parkia biglobosa.

In Parkia biglobosa, the growth units (GU) or macro-anatomical markers cor- 
respond to modules (MOD), due to a defined and limited growth of the axes generally caused by an apical trauma (death of apex), the axillary bud close to the apex thus takes over, until it also dies, and so on. The structure of the axis thus has a twisted appearance (Figure 2); we speak of a modular plant because of a succession of structures or several superposed modules [6] [34]. Indeed, the axis of these types of plants is a branched structure resulting from the functioning of several meristems and, depending on the number of branches formed, we speak of a monochasial (one relay axis), dichasial (two relay axes) or polychasial (several relay axes) sympod.

\section{4) Parameters evaluated}

The retrospective analysis focused on the first four growth modules (MODs) from the apical apex of the sampled axis. Morphological parameters assessed on each axis concerned the total number of modules carried by the observed axis, the length of each module, the diameter at the base of each module and the number of leaves or phytomers of the first four modules from the tip (apical start) of the sampled axes [1] [4] [35] [36]. The harvested stems and branches were split (longitudinal and transverse cuts) to identify growth stops (portions delimiting modules) imperceptible on the bark of the axes. Data were collected during the rainy season and this action was repeated on the same individuals during the dry season.

\subsubsection{Statistical Data Analysis}

Statistical analyses were first performed using one-dimensional descriptive statistics and linkage analysis methods using XLSTAT 2020 version 7.5. The
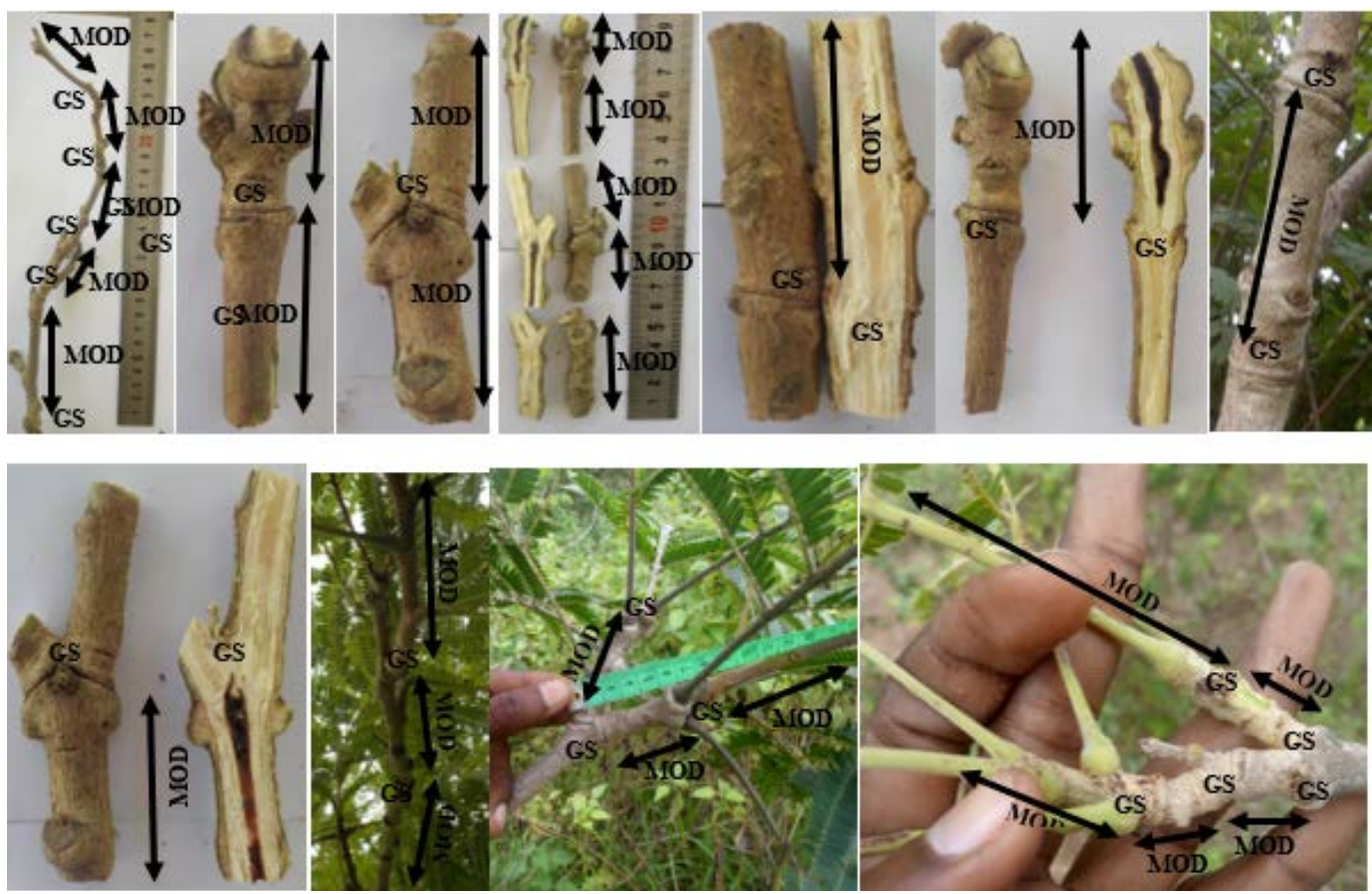

Figure 2. Images related to morphology and growth boundaries or growth stops (GS) of macro-anatomical markers or Growth modules (MOD) in Parkia biglobosa. 
difference between the evaluated parameters was carried out by means of oneway analyses of variance (ANOVA) with SAS software version 9.4. The StudentNewman-Keuls test at the $5 \%$ threshold was used for post hoc comparisons.

\section{Results}

\subsection{Architectural Development of the Individuals Observed}

According to the observations, the architectural development of the species is sympodial monochasial with only delayed relaying (delayed growth and branching). The terminal bud dies after a certain period of elongation, the axillary bud closest to the terminal bud takes over and so on. The plant appears as a pseudo-monopod with a twisted trunk structure. Parkia biglobosa can be classified in the architectural model of Paul Champagnat (1921-2011) and also of Wilhelm Troll (1897-1978) because of the way it builds its structure. Indeed, according to our remarks, the development of the species is a repeated complex of unbranched and discretely branched axes with short branches. The axes are vertical at their base and their distal end is by large radius curvature, reduced to horizontal or collapsed due to gravity and the flexibility of the wood. The leaves are spirally inserted and the flowering is sometimes lateral, sometimes terminal. In the young stage, the plant adopts the Champagnat pattern, while in adulthood and old age, the Troll pattern is more expressive.

\subsection{Morphological Characteristics of Growth Modules}

Globally, the number of growth modules carried by the observed axes varied from 2 to 26 with an average of $10.08 \pm 4.24$; the average length of the Modules varied from 3.85 to $51.40 \mathrm{~cm}$ with an average of $18.57 \pm 8.15 \mathrm{~cm}$; the average diameter of the Modules varied from 0.43 to $8.81 \mathrm{~cm}$ with an average of $1.43 \pm$ $0.82 \mathrm{~cm}$. The average number of phytomers counted per Module varied from 5.5 to 33.5 with an average of $15.09 \pm 5.35$. The morphology and limits of the growth modules are presented in Figure 2.

Figure 3 shows the average distribution of the number and length of phytomers per growth module (MOD) as well as the growth stop or growth boundary zones (GS) along a Parkia biglobosa axis.

\subsection{Influence of the Habitat on Growth Modules Morphology}

Analysis of the variance of modules morphological dimensions present on the observed axes according to the two environments considered (Table 3), showed that the morphology of the modules of the axes exposed to sunlight is statistically identical to the morphology of the modules of the axes benefiting from a superior shelter $(P>0.05)$. The environment in which this species evolves does not seem to have an effect on the dimensions of the modules. In Parkia biglobosa, the type of habitat (bright or dark light) does not significantly influence the morphology of the growth modules $(\mathrm{P}>0.05)$. 
Table 3. Comparison of modules morphological parameters according to the habitat type.

\begin{tabular}{ccccccc}
\hline Habitat & Tree-H $(\mathrm{m})$ & Tree-Diam $(\mathrm{cm})$ & Axis-Nbr-Mo & Mo-leng $(\mathrm{cm})$ & Mo-Diam $(\mathrm{cm})$ & Mo-Phyto-Nbr \\
\hline Full sun & $10.41 \pm 1.23 \mathrm{a}$ & $32.72 \pm 3.46 \mathrm{a}$ & $9.8 \pm 0.46 \mathrm{a}$ & $18.73 \pm 0.88 \mathrm{a}$ & $1.43 \pm 0.09 \mathrm{a}$ & $14.61 \pm 0.53 \mathrm{a}$ \\
Min-Max & $0.53-31.7$ & $0.56-178.44$ & $2-26$ & $3.85-51.4$ & $0.43-8.81$ & $5.5-30.5$ \\
Shadowing & $10.43 \pm 1.76 \mathrm{a}$ & $29.72 \pm 3.45 \mathrm{a}$ & $10.64 \pm 0.55 \mathrm{a}$ & $18.25 \pm 1.08 \mathrm{a}$ & $1.42 \pm 0.07 \mathrm{a}$ & $16.05 \pm 0.79 \mathrm{a}$ \\
Min-Max & $0.42-28.3$ & $1.26-113.44$ & $5-19$ & $6.25-41.5$ & $0.5-2.77$ & $6.5-33.5$ \\
Pr $>$ F & $\mathbf{0 . 9 7 7 1}$ & $\mathbf{0 . 5 2 1 3}$ & $\mathbf{0 . 2 6 8 5}$ & $\mathbf{0 . 7 4 4 0}$ & $\mathbf{0 . 9 2 8 0}$ & $\mathbf{0 . 1 2 7 7}$ \\
\hline
\end{tabular}

Values with the same letters are not statistically different at the $5 \%$ level. Tree-H $(\mathrm{m})=$ tree height in meters; Tree-Diam $(\mathrm{cm})=$ diameter at breast or crown height of the tree in centimetres; Axis-Nbr-Mo= number of modules or growth units carried by the measured axis; Mo-leng (cm)= average length of modules or growth units in centimeters.; Mo-Diam $(\mathrm{cm})=$ average diameter of modules or growth units in centimetres; $\mathbf{M o - P h y t o - N b r = ~ a v e r a g e ~ n u m b e r ~ o f ~}$ phytomers carried by the modules or growth units; $\mathbf{M i n}=$ minimum et $\mathbf{M a x}=$ maximum.

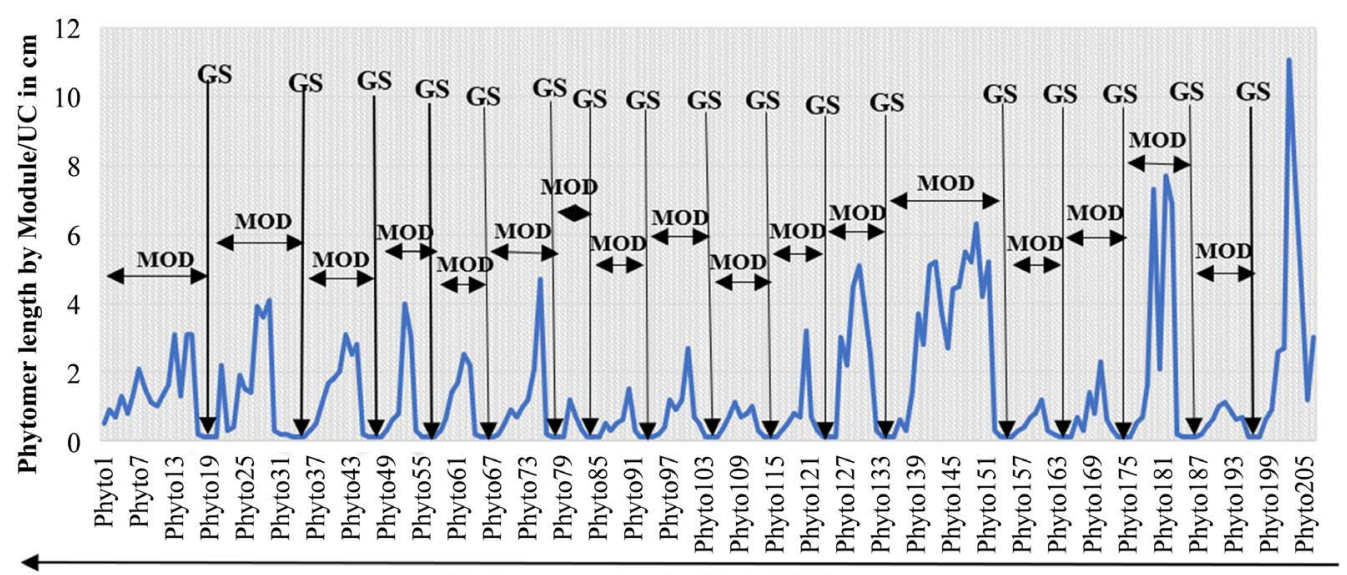

Apex (apical bud)

Phytomer number by Module/GU

Axis basis (towards the tree trunk)

Figure 3. Modelling of growth, rank and average distribution of the number of phytomeres by growth module along the observed axes in Parkia biglobasa. MOD/GU = Module or growth unit, GS = Growth stop or module limits, $\mathrm{cm}=$ Centimeter.

\subsection{Influence of the Surveyed Locations on Growth Modules Morphology}

The comparison of the measured parameters (Table 4) according to the locations, showed a significant difference between the locations visited for each parameter of module morphology evaluated $(\mathrm{P}<0.05)$. All module dimensions were neither increasing nor decreasing according to the arrangement of the localities along the defined South-North vegetation gradient. However, the modules were well developed in the localities of Bouake and Katiola in the south of the defined gradient. In Parkia biglobosa, the morphology of the modules differed according to the characteristics of the study area $(\mathrm{P}<0.05)$.

\subsection{Individuals Age Influence on the Growth Modules Morphology}

The results showed that the majority of the morphological parameters of the modules differed significantly between the ages $(\mathrm{P}<0.05)$, except for the mean diameter of the modules, which remained statistically identical regardless of age $(P>0.05)$. The number of modules per axis was higher in mature trees, while the 
Table 4. Variation of the morphological parameters of growth modules according to the localities surveyed.

\begin{tabular}{ccccccc}
\hline Localities & Tree-H $(\mathrm{m})$ & Tree-Diam $(\mathrm{cm})$ & Axis-Nbr-Mo & Mo-leng $(\mathrm{cm})$ & Mo-Diam (cm) & Mo-Phyto-Nbr \\
\hline Ferké & $15.51 \pm 3.76 \mathrm{a}$ & $55.28 \pm 7.87 \mathrm{a}$ & $9.39 \pm 1.61 \mathrm{~b}$ & $16.32 \pm 2.02 \mathrm{bc}$ & $1.51 \pm 0.08 \mathrm{ab}$ & $16.75 \pm 1.03 \mathrm{ab}$ \\
Min-Max & $2.3-29.5$ & $5.4-178.44$ & $5-17$ & $3.85-51.4$ & $0.87-3.2$ & $9.5-30.5$ \\
Korhogo & $12.86 \pm 2.09 \mathrm{ab}$ & $38.41 \pm 4.06 \mathrm{ab}$ & $10.14 \pm 0.55 \mathrm{abc}$ & $13.81 \pm 1.3 \mathrm{c}$ & $1.13 \pm 0.09 \mathrm{~b}$ & $12.36 \pm 0.94 \mathrm{bc}$ \\
Min-Max & $1.4-27.5$ & $2.3-84.4$ & $5-17$ & $4.23-26$ & $0.69-1.56$ & $6.75-19.75$ \\
Niakara & $15.98 \pm 1.33 \mathrm{a}$ & $46 \pm 3.59 \mathrm{a}$ & $11.32 \pm 0.87 \mathrm{a}$ & $19.69 \pm 1.51 \mathrm{~b}$ & $1.49 \pm 0.37 \mathrm{ab}$ & $20.69 \pm 0.62 \mathrm{a}$ \\
Min-Max & $2.4-28.5$ & $6.8-83$ & $7-18$ & $11.13-35.4$ & $0.95-2.77$ & $16-33.5$ \\
Katiola & $7.37 \pm 2.11 \mathrm{~b}$ & $21.37 \pm 3.5 \mathrm{~b}$ & $10.63 \pm 0.69 \mathrm{abc}$ & $23.01 \pm 1.35 \mathrm{ab}$ & $1.67 \pm 0.05 \mathrm{ab}$ & $15.5 \pm 0.69 \mathrm{~b}$ \\
Min-Max & $0.73-28.30$ & $1.25-113.44$ & $4-26$ & $11.93-38.95$ & $0.97-2.16$ & $8-20.5$ \\
Bouaké & $6.45 \pm 2.6 \mathrm{~b}$ & $20.46 \pm 7.86 \mathrm{~b}$ & $11.12 \pm 1.21 \mathrm{a}$ & $24.59 \pm 2.13 \mathrm{a}$ & $1.76 \pm 0.14 \mathrm{a}$ & $15.84 \pm 1.46 \mathrm{~b}$ \\
Min-Max & $1.14-31.7$ & $1.79-115.61$ & $3-19$ & $9.88-38.5$ & $0.65-2.73$ & $5.5-23.25$ \\
Toumodi & $11.35 \pm 0.02 \mathrm{ab}$ & $29.74 \pm 0.08 \mathrm{ab}$ & $12.2 \pm 0.52 \mathrm{a}$ & $20.55 \pm 1.15 \mathrm{~b}$ & $1.93 \pm 0.03 \mathrm{a}$ & $15.28 \pm 0.37 \mathrm{~b}$ \\
Min-Max & $0.77-30$ & $2.96-73$ & $5-19$ & $9.55-41.5$ & $1.01-8.81$ & $10-20.75$ \\
Daloa & $0.64 \pm 0.03 \mathrm{c}$ & $1.33 \pm 0.01 \mathrm{c}$ & $6 \pm 0.67 \mathrm{c}$ & $14.51 \pm 2 \mathrm{c}$ & $0.62 \pm 0.1 \mathrm{c}$ & $8.9 \pm 0.97 \mathrm{c}$ \\
Min-Max & $0.42-0.87$ & $0.56-2.04$ & $2-13$ & $9.3-31.6$ & $0.43-0.97$ & $6-12$ \\
Pr > F & $\mathbf{0 . 0 0 0 1}$ & 0.0001 & 0.0009 & 0.0001 & $\mathbf{0 . 0 0 8 9}$ & $\mathbf{0 . 0 0 0 1}$ \\
\hline
\end{tabular}

Values with the same letters are not statistically different at the 5\% level.

Table 5. Variation in modules morphological parameters according to the individuals sampled age.

\begin{tabular}{ccccccc}
\hline Ages & Tree-H $(\mathrm{m})$ & Tree-Diam $(\mathrm{cm})$ & Axis-Nbr-Mo & Mo-leng $(\mathrm{cm})$ & Mo-Diam $(\mathrm{cm})$ & Mo-Phyto-Nbr \\
\hline Old tree & $25.23 \pm 1.64 \mathrm{a}$ & $82.36 \pm 6.99 \mathrm{a}$ & $10.61 \pm 0.52 \mathrm{ab}$ & $16.92 \pm 0.97 \mathrm{~b}$ & $1.53 \pm 0.06 \mathrm{a}$ & $17.34 \pm 0.90 \mathrm{a}$ \\
Min-Max & $18-31.7$ & $60.1-178.44$ & $5-14$ & $5.05-26.3$ & $0.75-2.16$ & $10.5-30.5$ \\
Adult tree & $10.81 \pm 1.26 \mathrm{~b}$ & $37.47 \pm 2.32 \mathrm{~b}$ & $11.21 \pm 0.48 \mathrm{a}$ & $16.94 \pm 1.18 \mathrm{~b}$ & $1.59 \pm 0.16 \mathrm{a}$ & $15.82 \pm 0.59 \mathrm{a}$ \\
Min-Max & $7.5-13.7$ & $20-49.68$ & $6-19$ & $3.85-51.4$ & $0.69-8.81$ & $6.75-25.75$ \\
Young tree & $2.15 \pm 0.81 \mathrm{c}$ & $5.24 \pm 1.11 \mathrm{c}$ & $9 \pm 0.63 \mathrm{~b}$ & $20.52 \pm 1.1 \mathrm{a}$ & $1.26 \pm 0.07 \mathrm{a}$ & $13.56 \pm 0.72 \mathrm{~b}$ \\
Min-Max & $0.42-5.8$ & $0.56-18.96$ & $2-26$ & $9.2-41.5$ & $0.43-2.77$ & $5.5-33.5$ \\
Pr > F & $\mathbf{0 . 0 0 0 1}$ & $\mathbf{0 . 0 0 0 1}$ & $\mathbf{0 . 0 1 7 4}$ & $\mathbf{0 . 0 3 3 6}$ & $\mathbf{0 . 0 7 5 5}$ & $\mathbf{0 . 0 0 2 7}$ \\
\hline
\end{tabular}

Values with the same letters are not statistically different at the 5\% level.

average module length was higher in younger trees (Table 5). Old and mature trees had higher numbers of internodes per module than younger trees (Table 5). In Parkia biglobosa, the age of the individuals influenced the morphological dimensions of the growth modules $(\mathrm{P}<0.05)$.

\subsection{Influence of Humidity on the Growth Modules Morphology}

The average diameter of the growth modules did not vary significantly between seasons (Table 6); humidity did not have a major influence on the diameter of the growth modules ( $\mathrm{P}>0.05)$. In contrast, the number of modules per axis observed, the average length of growth modules and the average 
Table 6. Comparison of modules morphological dimensions according to season collection.

\begin{tabular}{|c|c|c|c|c|c|c|}
\hline Seasons & Tree-H (m) & Tree-Diam $(\mathrm{cm})$ & Axis-Nbr-Mo & Mo-leng (cm) & Mo-Diam (cm) & Mo-Phyto-Nbr \\
\hline Rainy & $10.87 \pm 1.04 \mathrm{a}$ & $35.3 \pm 2.79 \mathrm{a}$ & $11.6 \pm 0.38 \mathrm{a}$ & $27.02 \pm 1.07 \mathrm{a}$ & $1.47 \pm 0.13 \mathrm{a}$ & $16.09 \pm 0.72 \mathrm{a}$ \\
\hline Min-Max & $0.53-31.7$ & $0.56-178.44$ & $2-26$ & 4.23. - 51.4 & $0.45-8.81$ & $6.75-25.75$ \\
\hline Dryer & $9.94 \pm 1.47 \mathrm{a}$ & $27.91 \pm 4.07 \mathrm{a}$ & $8.47 \pm 0.53 \mathrm{~b}$ & $18.1 \pm 0.87 \mathbf{b}$ & $1.39 \pm 0.06 \mathrm{a}$ & $14.04 \pm 0.51 \mathrm{~b}$ \\
\hline Min-Max & $0.42-30$ & $0.9-85.5$ & $4-18$ & $3.85-41.5$ & $0.43-3.2$ & $5.5-33.5$ \\
\hline $\operatorname{Pr}>F$ & 0.3201 & 0.143 & 0.0001 & 0.0043 & 0.5666 & 0.0201 \\
\hline
\end{tabular}

Values with the same letters are not statistically different at the $5 \%$ level.

number of phytomer carried by growth modules differed significantly between seasons $(\mathrm{P}<0.05)$. The majority of the dimensions increased during the rainy season (Table 6). In Parkia biglobosa, humidity influenced the majority of the morphological dimensions of the growth modules $(\mathrm{P}<0.05)$, except the mean diameter $(\mathrm{P}>0.05)$.

\section{Discussion}

Growth dynamics in the crown of plants over the course of a season are the consequence of changes in architectural traits. How plants exploit and survive in a given environment, from an abiotic (climate) or biotic (interaction) point of view, is of key importance for their sustainable management. Sustainable management of plant genetic resources must take into account all possible aspects of scientific research, including architectural concepts (retrospective analysis) and the phenological cycle (diagnostic) of trees. This study addressed the effect of habitat, different localities along an environmental gradient, age of individuals and humidity on the morphology of growth modules carried by different axis types in Parkia biglobosa in Côte d'Ivoire.

\subsection{Development of Modules and Architectural Characters of Individuals}

The results showed that the boundaries of the Modules are represented by successively very short internodes (Figure 2 and Figure 3). These observations were found on Guayule (Parthenium argentatum) [37] [38] [39] and on Parkia velutina [1] etc. Parkia biglobosa has a sympodial architectural development with a single relaying axis (monochasial sympod), in contrast to Guayule (Parthenium argentatum) which is a sympod with several relay axes (polychasial sympod). Guayule belongs to the architectural model of Anthony Leeuwenberg like cassava. [34] indicated that Parkia biglobosa, of the Fabaceae family had an architectural development following the model of Wilhelm Troll, we think that the architectural model of this species also integrates that of Paul Champagnat according to our observations. This remains to be verified in further studies on the architectural analysis of Parkia biglobosa. 


\subsection{Habitat Influence on Growth Modules}

In our study, the environment in which the individuals evolved did not significantly influence the morphological dimensions of the growth modules $(\mathrm{P}>$ 0.05). This is due to the fact that we considered individuals of all age types observed in this environment in a global manner. The finding might be different if the observations on morphological dimensions were made only and separately by age category. Alternatively, this fact is due to the nature of the species; indeed, some species respect their own genetic programme of architectural development regardless of environmental stress [34]. Moreover, this species is a slow-growing savannah [9], and therefore the immediate perception of the effect of light on shoot growth might be difficult. Normally in a given plant, individuals in the shade (undergrowth) should be less developed than those exposed to the sun (full sun) as in the studies of [3] on Fagus sylvatica and of [40]. However, plants growing in the shade are very often tall and etiolated because of the terminal bud's search for bright light for photosynthetic activity. Indeed, bright light is the key factor for growth, it guarantees a good growth in length and width of plants contrary to dark light [40] [41] [42].

\subsection{Influence of Locality on Growth Modules}

The variation in morphological parameters between locations is due to the specific and distinct environmental characteristics of each location surveyed (climate, soil type, rainfall, relative humidity etc.). We had thought that the morphological dimensions of the measured Modules would be ordered in an increasing or decreasing manner according to the layout of the surveyed localities. This was not the case; in fact, even if the surveyed localities are arranged according to a "pseudo-climatic" gradient of dense vegetation decreasing towards the north, each locality has its own distinctive characteristics. Moreover, in the current context of climate change, climatic and microclimatic parameters are very unstable, uncontrolled and vary greatly within a day. Several studies have shown that the depth and fertility of the soil, the environment and even the age of individuals influence the architectural development of species [30] [42] [43]. [44] and [45] have also indicated in their research that climate or an ecological gradient has an effect on plant morphology. Similarly, studies by [46] and [47] [48] indicated that the origin of differences in tree morphology is due to factors such as soil type and the genetic characteristics of the individuals sampled. On the other hand, the modules were well developed in the southern part of the defining gradient (Bouaké and Katiola). This area could be a favourable and priority area for establishing permanent plots and increasing the success rate of reforestation or agroforestry programmes using this species.

\subsection{Influence of Individuals Age on the Growth Modules Morphology}

The morphological dimensions of the modules evaluated varied with the age of 
the individuals $(\mathrm{P}<0.05)$. The number of phytomeres per module is higher in old and mature trees, due to their age and the preformation of organs in the latent buds. In young trees, module length is higher due to the growth dynamics of young shoots (more intense meristematic activity). Indeed, some studies have shown that the age of individuals influences tree morphology [31] [43] [47] [48]. Age strongly modifies the morphological dimensions of plant organs regardless of location, due to very different functional capacities (number of photosynthetic leaves, evapotranspiration capacity, mineral storage, root suctions etc.) and structural dimensions (root and leaf sizes, space occupancy etc.). Young individuals with well-developed modules than the other two categories could be suitable ideotypes in the search for resilient genotypes adapted to global change for the establishment of plots based on this species by cuttings.

\subsection{Influence of Season}

In the rainy season the size of the modules increases. This period is favourable to the synchronised bud break of the terminal buds of the axes. In French Guiana, [1] observed the same phenomenon on Parkia velutina. The meristems of the buds, which have long remained dormant or in slow growth due to a long dry season, take advantage of this period to maximise their development. Indeed, water is vital for plants and its availability guarantees a good physiological and harmonious functioning of plants (metabolism, photosynthesis, organogenesis etc.). Whereas water stress slows down all physiological activity and causes their decline. [49] has indicated in his research the positive effects of water regime on plant growth and development. In the process of establishing a plot or implementing reforestation or agroforestry programmes based on Parkia biglobosa, the rainy season remains the best and most favourable period.

\section{Conclusion and Perspectives}

This study observed and identified the types of variation in the morphology of growth modules as a function of various abiotic parameters in Parkia biglobosa. It was found that the developmental environment of the plants did not significantly influence the dimensions of the growth modules $(P>0.05)$. While the morphological dimensions of the modules differed significantly between locations $(\mathrm{P}<0.05)$. The age of the individuals influences the size of the growth modules $(\mathrm{P}<0.05)$; with the exception of the average diameter of the modules, which remains identical regardless of age $(P>0.05)$. In the rainy season, the morphological dimensions of the modules increase significantly due to the favourable water regime for synchronised bud break of the terminal buds of the axes $(\mathrm{P}<0.05)$. From this study, we conclude that Parkia biglobosa is a monochasial sympod with a relay axis that follows Paul Champagnat's architectural model at the young stage and transitions to Wilhelm Troll's model later at the adult and old stage. We will try to confirm this in a future study on the architectural development of this species. This information contributes to the under- 
standing of the functioning of the crown and the adaptation of this species to various environments. It could guide the choice of the ideal environment for the establishment of a reforestation or agroforestry programme based on Parkia biglobosa.

\section{Acknowledgements}

This study was financed by the Ministry of Higher Education and Scientific Research of Côte d'Ivoire, the French Development Agency and IRD (Institut de Recherche pour le Developpement) in the framework of PRESeD-CI 2 (Renewed Partnership for Research for Development in Côte d'Ivoire) and C2D (Debt Reduction Contract) of the AMRUGE-CI project (Support for the Modernization and Reform of Universities and Grandes Ecoles of Côte d'Ivoire). The authors are grateful to the Centre de Coopération International de Recherche Agronomique pour le Développement (CIRAD) for providing the technical equipment necessary to conduct the study.

\section{Author's Declaration}

Beda Innocent Adji wrote the article, took the experimental measurements and analyzed the data. Doffou Sélastique Akaffou and Sylvie Annabel Sabatier contributed to methodology development and corrected the article. Kouadio Henri Kouassi, Jerôme Duminil and Yao Patrice Houphouet coordinated the research project.

\section{Data Availability}

The datasets generated during and/or analyzed in the current study are available from the corresponding author on reasonable request.

\section{Conflicts of Interest}

The authors have no conflict of interest to declare.

\section{References}

[1] Nicolini, E., Beauchêne, J., Leudet., De la Vallée, B., Ruelle, J., Mangenet, T. and Heuret, P. (2012) Dating Branch Growth Units in a Tropical Tree Using Morphological and Anatomical Markers: The Case of Parkia velutina Benoist (Mimosoïdeae). Annals of Forest Science, 69, 543-555. https://doi.org/10.1007/s13595-011-0172-1

[2] Sabatier, S., Caraglio, Y. and Drénou, C. (2014) L'architecture des arbres au service des forestiers. Innovations Agronomiques, 41, 119-128.

[3] Nicolini, E. and Caraglio, Y. (1994) L'influence de divers caractères architecturaux sur l'apparition de la fourche chez le Fagus sylvatica, en fonction de l'absence ou de la présence d'un couvert. Canadian Journal of Botany, 72, 1723-1734. https://doi.org/10.1139/b94-213

[4] Nicolini, E. (2000) Nouvelles observations sur la morphologie des unités de croissance du hêtre (Fagus sylvatica L.). Symétrie des pousses, reflet de la vigueur des arbres. Canadian Journal of Botany, 78, 77-87. https://doi.org/10.1139/cjb-78-1-77 
[5] Reinhardt, D. and Kuhlemeier, C. (2002) Plant Architecture. European Molecular Biology Organization (EMBO Reports), 3, 846-851. https://doi.org/10.1093/embo-reports/kvf177

[6] Barthélémy, D. and Caraglio, Y. (2007) Plant Architecture: A Dynamic, Multilevel and Comprehensive Approach to Plant Form, Structure and Ontogeny. Annals of Botany, 99, 375-407. https://doi.org/10.1093/aob/mcl260

[7] Rosati, A., Paoletti, A., Caporali, S. and Perri, E. (2013) The Role of Tree Architecture in Super High Density Olive Orchards. Scientia Horticulturae, 161, 24-29. https://doi.org/10.1016/j.scienta.2013.06.044

[8] Millan, M. (2016) Analyse de la variabilité des traits architecturaux des formes de croissance dans les communautés végétales. Thèse de Botanique. Université de Montpellier, Montpellier, $178 \mathrm{p}$.

[9] Sina, S. (2006) Reproduction et Diversité Génétique chez Parkia biglobosa (Jacq.) G.Don. PhD Thesis, Wageningen University, Wageningen, $102 \mathrm{p}$.

[10] Ouédraogo, A.S. (1995) Parkia biglobosa (Leguminosae) en Afrique de l'Ouest: Biosystématique et Amélioration. Thèse Doctorat Wageningen, University, Institute for Forestry and Nature Research, IBNDLO, 205p.

[11] Maisharou, A. and Larwanou, M. (2015) Market Potential of Non-Wood Forest Products in the Sahelian Countries. International Journal of Forestry Review, 17, 125-135. https://doi.org/10.1505/146554815816007018

[12] Avana-Tientcheu, M.L.A., Keouna, S., Dongock, N.D. and Mouga, M.B. (2019) Structure des peuplements et potentiel de domestication de Parkia biglobosa dans la région de Tandjilé-Ouest (Tchad). International Journal of Biological and Chemical Sciences, 13, 219-236. https://doi.org/10.4314/ijbcs.v13i1.19

[13] Détienne, P. (1995) Growth Ring Types and Occurrence in Some French Guianan Species. Bois et Forêt des Tropiques, 243, 65-75.

[14] N'dri, K.E., Gore, B.B.N. and Akaffou, D.S. (2019) Agro-Morphological Characterization of Myrianthus Arboreus (P. Beauv) in Cote d'Ivoire. International Journal of Advances in Scientific Research and Engineering, 5, 158-168. https://doi.org/10.31695/I]ASRE.2019.33450

[15] Louppe, D. and Ouattara, N. (1996) Les arboretums d'espèces locales en Nord Côte d'Ivoire. IDEFOR, 14 p. http://agritrop.cirad.fr/581418

[16] Hérault, B., Anatole, K.N., N’klo, O., Assandé, A., Fabrice, B., Brahima, C., Doua-Bi, Y., Koffi, Y., Koffi, K.J.C., Konaté, I., Tiéoulé, F., Wourro, F., Zo-Bi, I.C. and Louppe, D. (2020) The Long-Term Performance of 35 Tree Species of Sudanian West Africa in Pure and Mixed Plantings. Forest Ecology and Management, 468, 118171. https://doi.org/10.1016/j.foreco.2020.118171

[17] Djaha, J.B.A., N'da, A.A.A., Koffi, E.K., Ballo, C.K. and Coulibaly, M. (2012) Croissance et aptitude au greffage de deux génotypes d'anacardier (Anacardium occidentale L.) élites utilisées comme porte-greffe en Côte d'Ivoire. International Journal of Biological and Chemical Sciences, 6, 1453-1466. http://ajol.info/index.php/ijbcs https://doi.org/10.4314/ijbcs.v6i4.5

[18] Séka, K., Diallo, A.H., Kouassi, N.K. and Aké, S. (2009) Incidence du Yam mosaic virus (YMV) et du Cucumber mosaic virus (CMV) sur des variétés de Dioscorea spp. Cultivées dans les régions de Bouaké et de Toumodi en Côte d'Ivoire. International Journal Biological Chemic. Science, 3, 694-703. https://doi.org/10.4314/ijbcs.v3i4.47179

[19] N'cho, B.S. (1991) Modélisation de l'accès des racines de maïs (Zea mays) à l'azote. Expérimentation au champ en Centre Côte d'Ivoire. Mémoire de DIAT-ESAT, Mont- 
pellier, $22 \mathrm{p}$.

[20] Ettien, D.J.B. (2004) Intensification de la production d'igname (Dioscorea spp) par la fertilisation minérale et l'identification de nouvelles variétés en zone forestière et savanicole de Côte d'Ivoire. Thèse de Doctorat unique en science de la terre, option Agro-pédologie, Université de Cocody, Abidjan, 187 p.

[21] Akassimadou, G. and Yao, K. (2014) La variabilité climatique en Côte d'Ivoire: entre perception sociales et réponse agricole. Cahier Agriculture, 14, 533-540.

[22] Traoré, k., Sorho, F., Dramane, D.D. and Sylla, M. (2013) Adventices hôtes alternatifs de virus en culture de Solanaceae en Côte d'Ivoire. Agro Africa, 25, 231-237.

[23] N'zi, J.C., Kouame, C. and N'guetta, A.S.P. (2019) Influence de quelques paramètres climatiques sur les effectifs de Bemisia tabaci sur la tomate (Solanum lycopersicum L.). International Journal of Biological and Chemical Sciences, 13, 338-352. https://doi.org/10.4314/ijbcs.v13i1.27

[24] Coulibaly, L., Kouassi, K.H., SORO, G.E and Savane, I. (2016) Analyse du processus de savanisation du nord de la Côte d'Ivoire par télédétection: Cas du département de Ferkessédougou. International Journal of Innovation and Applied Studies, 17, 136-143. http://www.ijias.issr-journals.org/

[25] N'guessan, K.A., Diarassouba, N., Alui, K.A., Nangha, K.Y., Fofana, I.J. and YaoKouamé, A. (2015) Indicateurs de dégradation physique des sols dans le Nord de la Côte d'Ivoire: Cas de Boundiali et Ferkessédougou. Afrique Science, 11, 115-128.

[26] Coulibaly, T.J.H. (2009) Répartition spatiale, gestion et exploitation des eaux souterraines: cas du département de Katiola, région des savanes de Côte d'Ivoire. Thèse de Doctorat, Sciences de la Terre. Université Paris-Est, 142 p. https://tel.archives-ouvertes.fr/tel-00638690

[27] Soro, T.D., Kouakou, B.D., Kouassi, E.A., Soro, G., Kouassi, A.M., Kouadio, K.E., Yéi, M.S.O. and Soro, N. (2013) Hydroclimatologie et dynamique de l'occupation du sol du bassin versant du Haut Bandama à Tortiya (Nord de la Côte d'Ivoire). VertigO-La revue électronique en sciences de lenvironnement, 13, 23 p. https://doi.org/10.4000/vertigo.14468

[28] Adjanohoun, E. (1964) Végétation des savanes et des rochers découverts en Côte d'ivoire Centrale. Rapport, Office de la recherche scientifique et technique outreMer, Centre ORSTOM d'Adiopodoumé-Abidjan, 238 p.

[29] Hallé, F and Martin, R. (1968) Etude de la croissance rythmique chez l'Hévéa (Hevea brasiliensis Mull. Arg.). Adansonia, Série 2, 8, 475-503.

[30] Sabatier, S. (1999) Variabilité morphologique et architecturale de deux espèces de Noyers: Juglans regia L., Juglans nigra L. et deux Noyers hybrides interspecifiques. Thèse de Doctorat, Biologie végétale, sciences et techniques du Languedoc, Université de Montpellier II, 143 p. https://tel.archives-ouvertes.fr/tel-00106305

[31] Sabatier, S. and Barthélémy, D. (1999) Growth Dynamics and Morphology of Annual Shoots According to Their Architectural Position in Young Cedrus atlantica (Endl.) Manetti ex Carrière (Pinaceae). Annals of Botany, 84, 387-392. https://doi.org/10.1006/anbo.1999.0939

[32] Thiébaut, B. (1982) Observations sur le développement de plantules de hêtre (Fagus sylvatica) cultivés en pépinières, orthotropie et plagiotropie. Canadian Journal of Botany, 60, 1292-1303. https://doi.org/10.1139/b82-165

[33] Hallé, F., Oldeman, R.A.A. and Tomlinson, P.B. (1978) Tropical Trees and Forests: An Architectural Analysis. Springer-Verlag, Berlin.

https://doi.org/10.1007/978-3-642-81190-6

[34] Hallé, F. and Keller, R. (2019) Mais d'où viennent les plantes? Actes sud., 179 p. 
[35] Sabatier, S., Barthélémy, D., Ducousso, I. and Germain, E. (1998) Modalités d'allongement et morphologie des pousses annuelles chez le noyer commun, Juglans regia L. 'Lara' (Juglandaceae). Canadian Journal of Botany, 76, 1253-1264. https://doi.org/10.1139/b98-055

[36] Godin, C. and Caraglio, Y. (1998) A Multiscale Model of Plant Topological Structures. Journal of Theoretical Biology, 191, 1-46. https://doi.org/10.1006/jtbi.1997.0561

[37] Taurines, M., Brancheriau, L., Palu, S., Pioch, D., Tardan, E., Boutahar, N., Sartre, P. and Meunier, F. (2019) Determination of Natural Rubber and Resin Content of Guayule Fresh Biomass by Near Infrared Spectroscopy. Industrial Crop \& Products, 134, 177-184. https://doi.org/10.1016/j.indcrop.2019.03.073

[38] Jaeger, M., Sabatier, S.A., De Reffye, P., Alsater, A.A. and Brancheriau, L. (2020) Efficient Stochastic Functional Structural Sympodial Shrubs Modelling Base Donstructural Hierarchy. Application to Guayule. FSPM 2020: Towards Computable Plants, Leibniz, Germany, hal-03105340.

[39] Brancheriau, L., Sabatier, A.S., Jaeger, M., Hemery, N. and Mougani, C. (2020) Modelling the Guayule Plant Growth and Development with a Functional Structural Plant Model. FSPM towards Computable Plants. 9th International Conference on Functional-Structural Plant models, Hanovre, hal-03056119.

[40] Tousignant, M.E. and Delorme, M. (2006) Connaître le fonctionnement de la plante pour mieux gérer son environnement. Article paru dans Québec Vert (IQDHO). Adapté de Understanding Plant Growth: A Review of the Basics. Conférence présentée lors de l'Ohio International Short Course 2005 par Paul A. Thomas et Bodie V. Pennisi, de l'Université de Georgie, et bonifié par l'équipe de l'IQDHO, 3 p.

[41] Abidi, F. (2012) Effets de la qualité de la lumière sur l'élaboration de l'architecture du rosier buisson. Thèse de doctorat, l'Université de Tunis El Manar, Tunisie, 277 p.

[42] Calonnec, A. (2013) Façonner l'architecture végétale pour contrôler les maladies des plantes. BIOFUTUR, 343, 37-42.

[43] Lauri, P.E., Kelner. J.J., Trottier, J.C and Costes, E. (2010) Insights into Secondary Growth in Perennial Plants: Its Unequal Spatial and Temporal Dynamics in the Apple (Malus domestica) Is Driven by Architectural Position and Fruit Load. Annals of Botany, 105, 607-616. https://doi.org/10.1093/aob/mcq006

[44] Maranz, S. and Wiesman, Z. (2003) Evidence for Indigenous Selection and Distribution of the Shea Tree, Vitellaria paradoxa, and Its Potential Significance to Prevailing Parkland Savanna Tree Patterns in Sub-Saharan Africa North of the Equator. Journal of Global Biogeography, 30, 1505-1516. https://doi.org/10.1046/j.1365-2699.2003.00892.x

[45] Soloviev, P., Niang, T.D., Gaye, A. and Totte, A. (2004) Variabilité des caractères physicochimiques des fruits de trois espèces ligneuses de cueillette, récoltés au Sénégal, Adansonia digitata, Balanites aegyptiaca et Tamarindus indica. Fruits, 59, 109-119. https://doi.org/10.1051/fruits:2004011

[46] Salazar, R. and Quesada, M. (1987) Provenance Variation in Guazuma ulmifolia L. in Costa Rica. Commonwealth Forestry Review, 66, 317-324.

[47] Assogbadjo, A.E., Sinsin, B., Codjia, J.T.C. and Van Damme, P. (2005) Ecological Diversity and Pulp, Seed and Kernel Production of the Baobab (Adansonia digitata) in Benin. Belgian Journal of Botany, 138, 47-56.

[48] Assogbadjo, A.E., Kyndt, T., Sinsin, B., Gheysen, G. and Van Damme, P. (2006) Patterns of Genetic and Morphometric Diversity in Baobab (Adansonia digitata L.) Populations across Different Climatic Zones of Benin (West Africa). Annals of Botany, 97, 819-830. https://doi.org/10.1093/aob/mcl043 
[49] Meridja, S. (2011) Approche biophysique des processus de développement et de croissance des couverts végétaux: Interaction avec le stress hydrique et optimisation des pratiques culturales en climat méditerranéen. Thèse en Sciences agricoles, AgroParisTech, Français, NNT: 2011AGPT0057, pastel-00776775, 180 p. 